\title{
Expanded Range Limits of Boreal Birds in the Torngat Mountains of Northern Labrador
}

\author{
DARROCH WHITAKER
}

Parks Canada, P. O. Box 130, Rocky Harbour, Newfoundland and Labrador A0K 4N0 Canada; email: darroch.whitaker@pc.gc.ca

Whitaker, Darroch. 2017. Expanded range limits of boreal birds in the Torngat Mountains of Northern Labrador. Canadian Field-Naturalist 131(1): 55-62. https://doi.org/10.22621/cfn.v131i1.1957

The Torngat Mountains lie at the southeastern limit of the Canadian Arctic in northern Labrador, and bird distributions in the region are poorly understood. I visited the Torngat Mountains every summer from 2008 to 2016 and recorded all birds observed. Several boreal bird species were widespread and breeding in the region, representing expansion of known ranges by 100-350 km north along the Labrador coast and 40-90 km east from Ungava Bay. Shrub thickets have expanded dramatically in the Torngat Mountains since the 1980s; thus, these observations may reflect range expansion by boreal birds in response to increased habitat availability.

Key Words: Boreal birds; climate change; Labrador; range shifts; shrubification; Torngat Mountains; treeline

\section{Introduction}

Understanding and monitoring the range limits of species can offer important insights into environmental change and valuable information for conservation planning in a changing world. Environmental change is progressing rapidly in northern Canada, particularly along the boreal-arctic ecotone and is evident in the form of both climate change and widespread expansion of shrub communities ("shrubification"; Myers-Smith et al. 2011, 2015; IPCC 2014). Many species of birds have also shifted their ranges poleward in North America and Eurasia, a phenomenon that has been linked to climate change, although most such evidence comes from sub-arctic biomes (e.g., Thomas and Lennon 1999; Brommer 2004; Hitch and Leberg 2007; Chen et al. 2011). Although atlas projects and citizen science initiatives have provided detailed information on the breeding distribution of bird species throughout much of southern Canada (e.g., Cadman et al. 2007), such information across Canada's North remains limited and imprecise.

As in much of the Arctic, the environment of northern Labrador is changing rapidly. Average air temperature has increased by about $2^{\circ} \mathrm{C}$ since the early $1990 \mathrm{~s}$ and is expected to increase by another $2-4^{\circ} \mathrm{C}$ by 2050 (Allard and Lemay 2012; Finnis 2013; Way and Viau 2014). Coupled with this, growing seasons are becoming longer, with increases of about 20 days forecast by 2050 (He et al. 2008; Pouliot et al. 2009; Allard and Lemay 2012). These changes have implications for vegetation communities, and both remote sensing and Inuit knowledge indicate that cover of tall shrubs, including willow (Salix sp.), alder (Alnus sp.), and Dwarf Birch (Betula glandulosa), has increased approximately six-fold in the Torngat Mountains of northern Labrador since the 1980s (Parks Canada 2008; Fraser et al. 2011; Quirouette and Zorn 2015). Shrubification is occurring across much of the Arctic (Myers-Smith et al. 2011, 2015), but the rate of change is much higher in the Torngat Mountains than in other parts of the Canadian North (Fraser et al. 2011; see also Tremblay et al. 2012). This may be the result of an interactive functional response of existing shrubs to climate amelioration combined with a large drop in grazing pressure with the decline of the Torngat Mountains Caribou (Rangifer tarandus) herd (Wilson et al. 2014; Christie et al. 2015; Couturier et al. 2015).

Studies of bird distributions in northern Labrador have been limited, although a number of ornithologists and naturalists have travelled the region over the past century, and their observations are well documented. Key historical works include those of Austin (1932) and Todd (1963), who report observations from more than 25 expeditions to Labrador and northern Quebec between 1901 and 1958 and also thoroughly review reports from numerous other naturalists who have travelled the region. More recently, Al Veitch spent five seasons at Hebron Fiord (1989-1993) and kept detailed records of his bird observations, which were summarized by Harrington (1994). These records are valuable because they offer detailed information about a seldomsurveyed location near the range limits of many species just before climate and vegetation change accelerated in the region.

From 2008 to 2016, I made annual summer visits to the Torngat Mountains, during which I travelled extensively between Saglek Bay and Seven Islands Bay. The survey area overlapped that of Austin (1932) and Todd (1963) and is 10-20 km north of the area travelled by Veitch (Harrington 1994). During these visits, I recorded information on the distribution and breeding status of all birds observed. Here I compare my observations with documented breeding limits for several species of boreal birds. 


\section{Methods}

The Torngat Mountains ecoregion (Notzl et al. 2013) represents the southeastern limit of the Canadian Arctic Cordillera and spans the northernmost $\sim 300 \mathrm{~km}$ of Labrador from Mugford Bay in the south to Killiniq Island in the north (Figure 1). The region is dominated by the Torngat Mountains, with summits exceeding $1500 \mathrm{~m}$, large river valleys, and a complex coast that includes numerous islands, bays, and fiords. Torngat Mountains National Park $\left(9700 \mathrm{~km}^{2}\right)$ was established in 2005 and occupies the northern half of the ecoregion.

The boreal-arctic ecotone (i.e., the "treeline") in Labrador occurs in the vicinity of Okak (Payette 1983) about $120 \mathrm{~km}$ south of the park, and the Torngat Mountains are dominated by arctic vegetation. However, some northern boreal plant communities are found in favourable habitat north of Okak, including small isolated stands of Black Spruce (Picea mariana (Mill.) Britton, Sterns \& Poggenb.) as far north as Hebron Fiord and a handful of small (i.e., $<1$ ha) stands of Balsam Poplar (Populus balsamifera L.) and Mountain Ash (Sorbus americana Marshall) around Saglek Fiord. Dense 1-4 m tall willow and alder thickets are found in riparian areas and the lower slopes of valleys, but are increasingly sparse in the north and reach a limit near the Eclipse River. To the west in Quebec, conifer stands extend farther north along the George River and in sheltered valleys along the coast of Ungava Bay, reaching a northern limit at Abloviak Fiord (Payette 1983). Black Spruce and Eastern Larch (Larix laricina (Du Roi) K. Koch) also extend far inland in the Koroc River Valley, where scattered stands reach a limit near the headwaters of Nakvak Brook (Ouellet 1978; Payette 1983; KRG 2005).

Observations reported here were made during nine years of summer fieldwork in Torngat Mountains National Park (2008-2016), including some made just south of the park. During these visits, I documented all birds observed following an approach similar to that employed in breeding bird atlas studies (e.g., Cadman et al. 2007); for each encounter, I recorded species, date, location, and evidence of breeding (Table 1). Although opportunistic, this approach allowed rapid as- sessment of bird communities at many coastal and inland sites and yielded over 1400 observations of 76 species (data available from eBird [http://ebird.org/] or Natureserve [www.natureserve.org] or upon request to D.W.).

However, there were limitations to this approach. Most notably, visits were limited to 3-5 weeks between mid-July and late August each year; thus, it was not possible to observe birds at the peak of breeding in June and early July when they would have been singing and displaying more aggressively. The timing also increased the likelihood of observing post-breeding individuals that may have immigrated from other areas, such as conifer forests along the Ungava coast. Operational constraints limited my travels to the region between Saglek Bay and Kangalaksiorvik Lake, which spans about $100 \mathrm{~km}$ at the centre of the Torngat Mountains ecoregion but does not encompass the northernmost $\sim 100 \mathrm{~km}$ of Labrador or the $\sim 120 \mathrm{~km}$ gap between Saglek and the boreal ecotone near Okak (Figure 1).

\section{Results and Discussion}

My observations from 2008 to 2016 indicate that several northern boreal bird species are far more widespread and abundant in the central Torngat Mountains than has been reported previously (Table 2). Further, I found evidence that most of these species are occasionally or regularly breeding 10 s to 100 s of kilometres north and east of previously reported range limits (Table 2). Admittedly, available historical information on the distribution of these species is incomplete and biased toward more accessible coastal locations. However, it seems implausible that the ornithologists and other naturalists who visited the region over a period of more than 100 years would have consistently missed a whole suite of northern boreal birds. This is especially true given that these species are all found in and around willow and alder thickets that are easily accessed along the coast; because they have the greatest diversity and abundance of birds in the region these thickets would surely have attracted the attention of observers. Thus, it seems likely that the breeding ranges or at least the abundance of several northern boreal birds has increased in the central Torngat Mountains in recent decades.

TABLE 1. Behavioural observations used to assess the breeding status of birds observed in the Torngat Mountains of northern Labrador, 2008-2016.

\begin{tabular}{ll}
\hline \hline Breeding status & Behavioural evidence \\
\hline No evidence of breeding & No behaviour or physical evidence suggestive of breeding \\
Possible breeding & Seen or heard singing in nesting habitat during breeding period \\
& Pair seen in nesting habitat \\
& Territorial nesting behaviour in nesting habitat for $>1$ week \\
& Courtship between male and female \\
& Visiting possible nest site \\
Confirmed breeding & Nest building \\
& Distraction display \\
& Recently fledged or downy young \\
& Adult carrying food or fecal sac \\
& Nest with eggs, egg shells, or young \\
\hline \hline
\end{tabular}




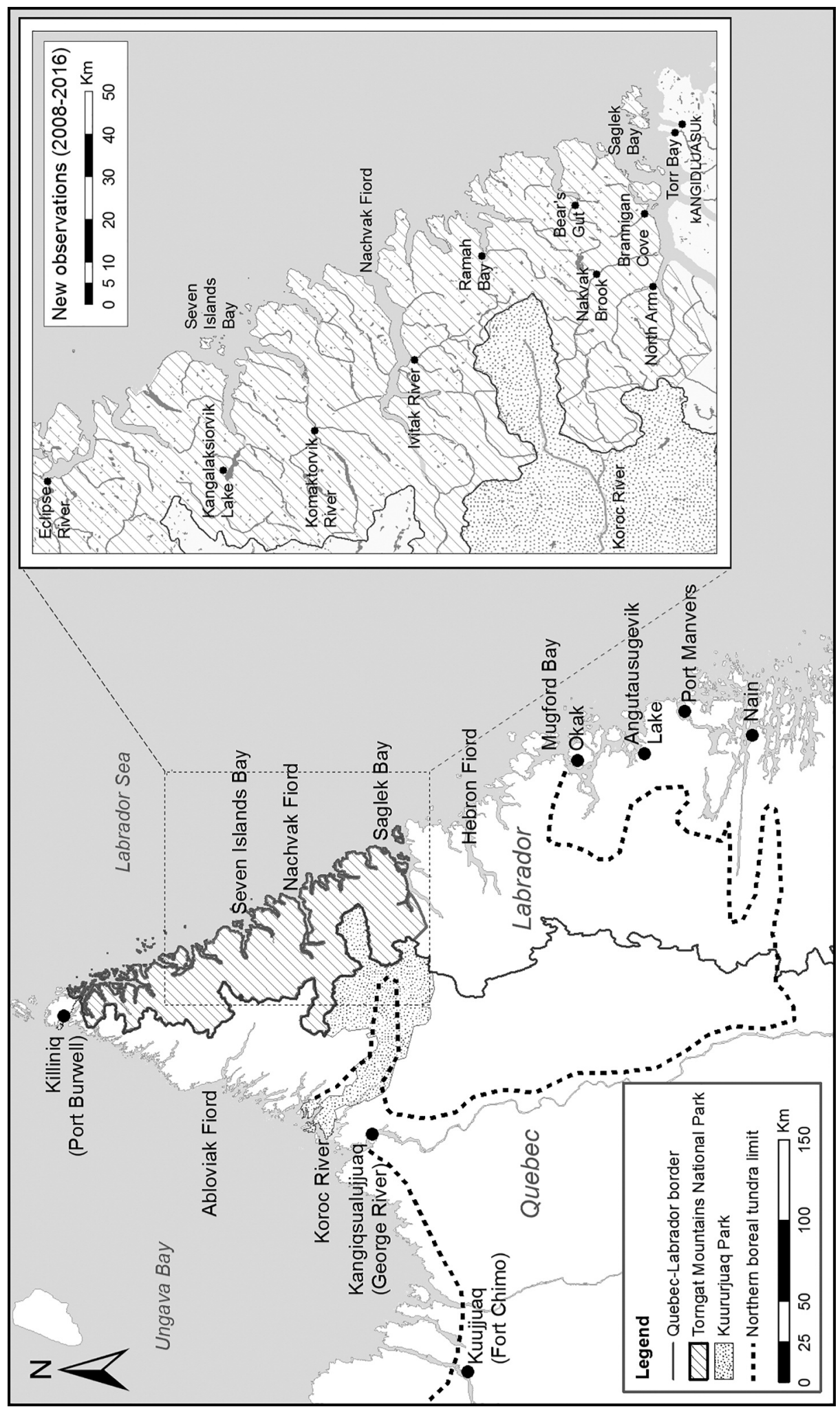

 


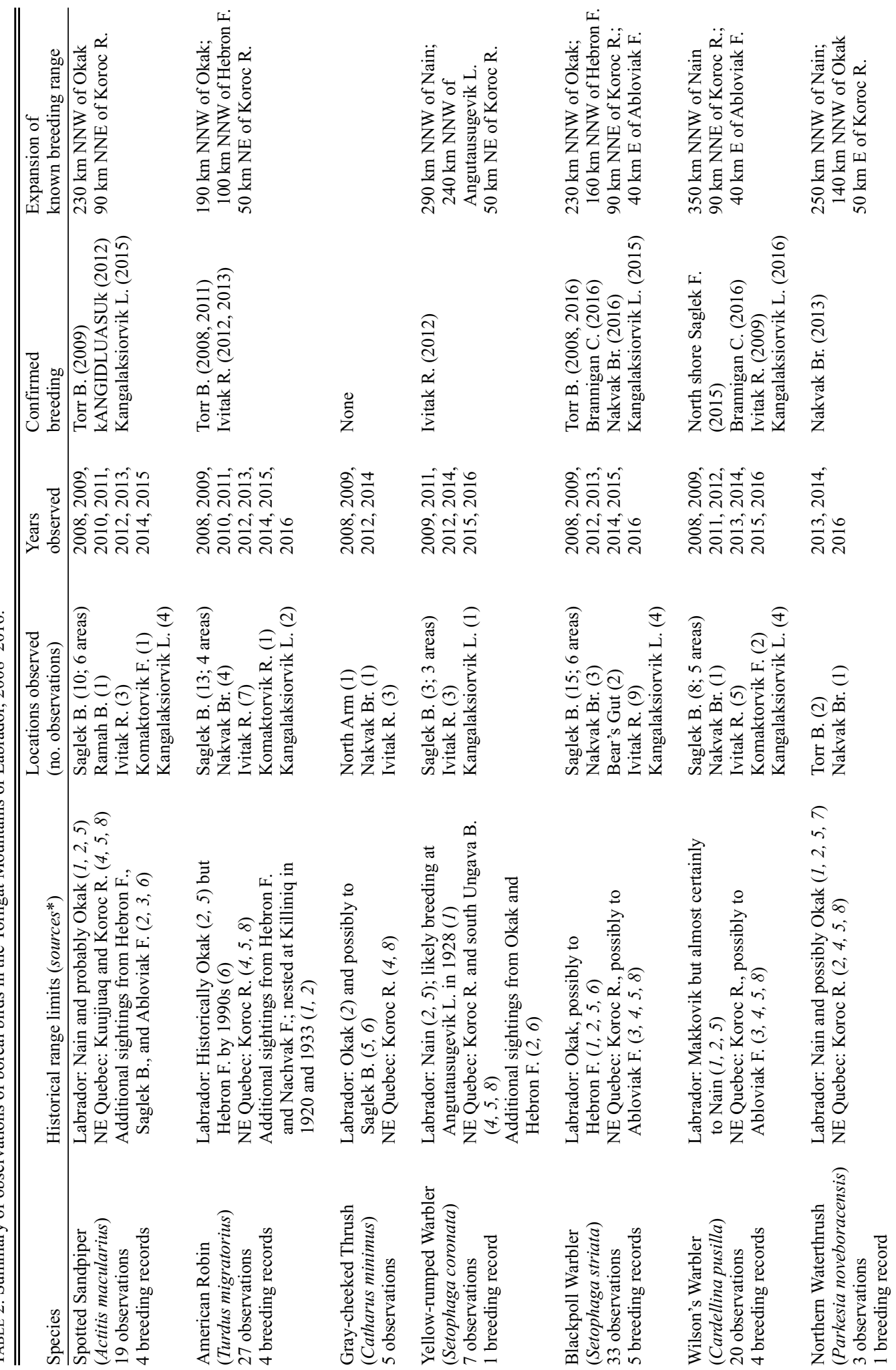




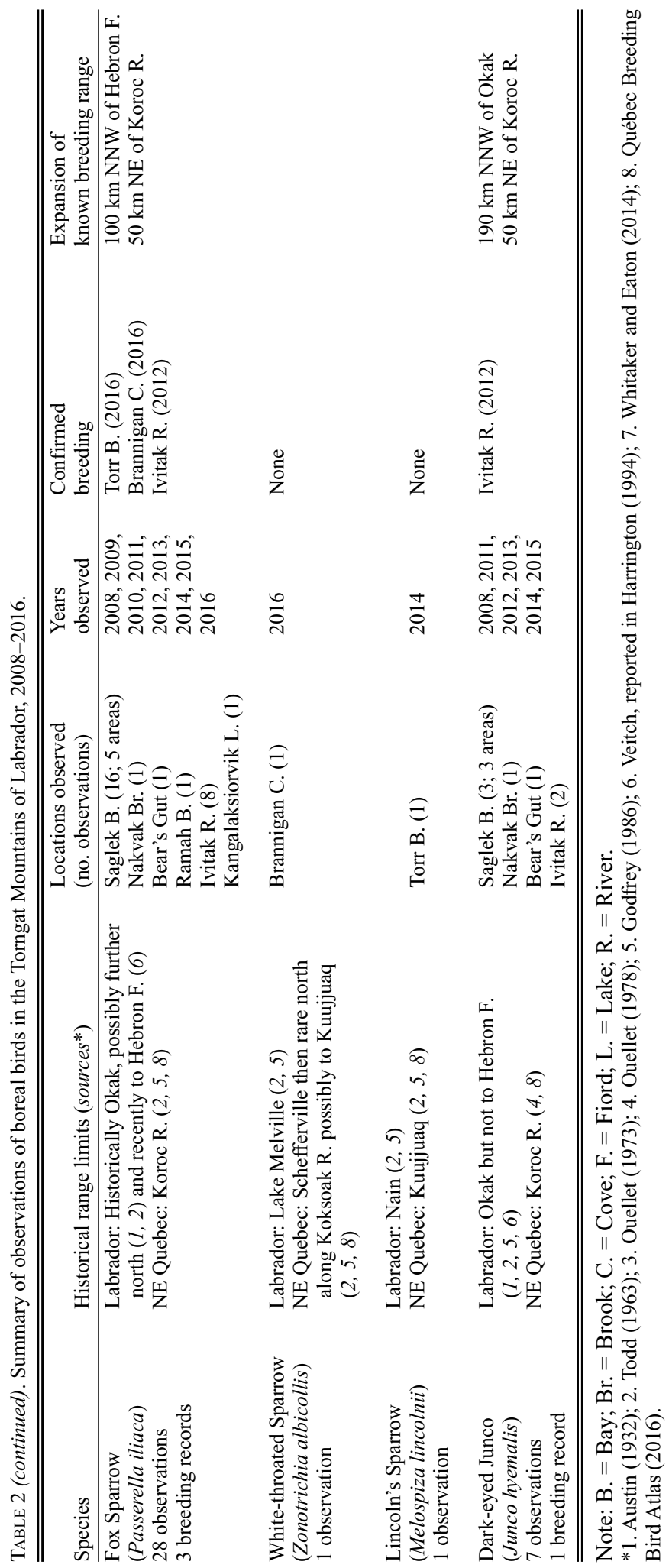


Some of these species are well established and widespread in suitable habitat (Spotted Sandpiper [Actitis macularius], American Robin [Turdus migratorius], Blackpoll Warbler [Setophaga striata], Wilson's Warbler [Cardellina pusilla], Fox Sparrow [Passerella ili$a c a]$ ), while others were infrequently observed (Graycheeked Thrush [Catharus minimus], Yellow-rumped Warbler [Setophaga coronta], Northern Waterthrush [Parkesia noveboracensis], Dark-eyed Junco [Junco hyemalis]). Lincoln's Sparrow (Melospiza lincolnii) and White-throated Sparrow (Zonotrichia albicollis) are more southern species that were only seen once and, thus, were likely vagrants.

Although several studies have shown that many bird species are shifting their ranges poleward, this process does not appear to be directly constrained by ambient temperature, as most tolerate colder temperatures in their breeding range than occur at their poleward range limit (Coristine and Kerr 2015). Rather, range limits may be constrained by composite climatic factors, lags in the expansion of plant communities that afford appropriate breeding and foraging habitat, geographic barriers, competition, and intrinsic life history traits (Bateman et al. 2015; Coristine and Kerr 2015; Stralberg et al. in press). With the exception of Spotted Sandpipers, which were seen primarily along shorelines, the boreal birds I encountered were most often found in and around low-lying willow and alder thickets. American Robins, Fox Sparrows, and Dark-eyed Juncos were somewhat more catholic, also making regular use of Dwarf Birch thickets and other tundra shrub habitats and occurring in both low-lying areas and on the midslopes of valleys and fiords. Thus, it seems likely that expansion of boreal birds in the central Torngat Mountains has been facilitated by the recent rapid expansion of tall shrub habitats in the region. Such shrubification is becoming widespread in the Arctic, albeit typically at a much slower rate, so a similar trend of increasing habitat availability for many northern boreal and Taiga bird species is expected throughout the North (Sokolov et al. 2012; Henden et al. 2013; Boelman et al. 2015; Mizel et al. 2016). Given their high mobility, birds are physically capable of rapidly tracking expansion of suitable breeding habitat, and, consistent with Stralberg et al. (in press), my observations suggest that mountainous terrain per se has not hindered this process in northern Labrador. Indeed, I regularly found several boreal birds in small riparian shrub thickets in isolated river valleys separated by large bays and fiords and highlands exceeding $1000 \mathrm{~m}$.

Future changes in bird communities of the Torngat Mountains are difficult to predict and will depend on the habitat needs of individual species (Thompson et al. 2016). A number of conifer-associated boreal birds (e.g., Spruce Grouse [Falcipennis canadensis], Gray Jay [Perisoreus canadensis], and Boreal Chickadee [Poecile hudsonicus]) also breed along the Koroc River (Ouellet 1978; Québec Breeding Bird Atlas 2016).
However, expansion of such species into northern Labrador seems improbable unless conifers spread into the region first, a process that may take many decades if it occurs at all. It is also unclear whether the species I observed in the central Torngat Mountains could eventually occupy the entire Ungava Peninsula. The shrub expansion that has been documented to date is most pronounced in the southern and central Torngat Mountains (Fraser et al. 2011; Quirouette and Zorn 2015), and well developed shrub tickets are rare north of the Eclipse River. Thus, shrubification in the northernmost Torngat Mountains may be increasingly constrained by plant dispersal rather than simple infilling and growth of existing shrubs and, as a result, may proceed at a slower rate (Myers-Smith et al. 2011, 2015). Further, if the Caribou herd in the Torngat Mountains recovers and grazing pressure returns to past levels, then shrubs may once again become suppressed, with negative consequences for any associated bird species (e.g., Ims and Henden 2012; Henden et al. 2013; Christie et al. 2015).

\section{Acknowledgements}

Observations reported here include some made with or reported by other Parks Canada staff, bear monitors from Torngat Mountains Base Camp and Research Station, participants in the kANGIDLUASUk Student Program and other researchers. In particular these include Dorothy Agnatok, Andrew Andersen, Joe Atsatata, Geoff Goodyear, Elias Harris, Robert Harris, Harry Hay, Luise Hermanutz, Brandon Holden, Rodd Laing, Martin Lougheed, Donald McLennan, Boonie Merkuratsuk, Eli Merkuratsuk, Jacko Meruratsuk, John Merkuratsuk, Jobie Unatweenuk, and Stephen Woodley. Finally Michel Gosselin of the Canadian Museum of Nature kindly shared Henri Ouellet's field notes and reports from Ungava Bay. This work is dedicated to Dorothy Agnatok, who's memory will forever be a part of the landscape of the Torngat Mountains for me and the many other people she touched.

\section{Literature Cited}

Allard, M., and M. Lemay. 2012. Nunavik and Nunatsiavut: from science to policy, an Integrated Regional Impact Study (IRIS) of climate change and modernization. AcrticNet Inc., Québec, Quebec, Canada.

Austin, O. L. 1932. The Birds of Newfoundland Labrador. Memoirs of the Nuttall Ornithological Club, no. VII. Nuttall Ornithological Club, Cambridge, Massachusetts, USA.

Bateman, B. L., A. M. Pidgeon, V. C. Radeloff, J. VanDerWal, W. E. Thogmartin, S. J. Vavrus, and P. J. Heglund. 2015. The pace of past climate change vs. potential bird distributions and land use in the United States. Global Change Biology 22: 1130-1144. https://doi.org/10.1111/gcb .13154

Boelman, N. T., L. Gough, J. Wingfield, S. Goetz, A. Asmus, H. E. Chmura, J. S. Krause, J. H. Perez, S. K. Sweet, and K. C. Guay. 2015. Greater shrub dominance alters breeding habitat and food resources for migratory songbirds in Alaskan arctic tundra. Global Change Biology 21: 1508-1520. https://doi.org/10.1111/gcb.12761 
Brommer, J. E. 2004. The range margins of northern birds shift polewards. Annales Zoologici Fennici 41: 391-397.

Cadman, M. D., D. A. Sutherland, G. G. Beck, D. Lepage, and A. R. Couturier. 2007. Atlas of the Breeding Birds of Ontario, 2001-2005. Bird Studies Canada, Environment Canada, Ontario Field Ornithologists, Ontario Ministry of Natural Resources, and Ontario Nature, Toronto, Ontario, Canada.

Chen, I. C., J. K. Hill, R. Ohlemuller, D. B. Roy, and C. D. Thomas. 2011. Rapid range shifts of species associated with high levels of climate warming. Science 333: 10241026. https://doi.org/10.1126/science. 1206432

Christie, K. S., J. P. Bryant, L. Gough, V. T. Ravolainen, R. W. Ruess, and K. D. Tape. 2015. The role of vertebrate herbivores in regulating shrub expansion in the Arctic: a synthesis. BioScience 65: 1123-1133. https://doi.org/10 $.1093 /$ biosci/biv137

Coristine, L. E., and J. T. Kerr. 2015. Temperature-related geographical shifts among passerines: contrasting processes along poleward and equatorward range margins. Ecology and Evolution 5: 5162-5176. https://doi.org/10.1002/ece3 .1683

Couturier, S., A. Dale, J. Mitchell Foley, J. Snook, and B. Wood. 2015. First scientific data on herd size and population dynamics of the Torngat Mountains caribou herd. Technical report. Torngat Wildlife, Plants and Fisheries Secretariat, Happy Valley Goose Bay, Newfoundland and Labrador, Canada. https://doi.org/10.13140/RG.2.1.3213 .1043

Finnis, J. 2013. Predicted impacts of climate change on the province of Newfoundland and Labrador. Report to the Newfoundland and Labrador Office of Climate Change, Energy Efficiency and Emissions Trading. Department of Geography, Memorial University, St. John's, St. John's, Newfoundland and Labrador, Canada.

Fraser, R. H., I. Olthof, M. Carrier, A. Deschamps, and D. Pouliot. 2011. Detecting long-term changes to vegetation in northern Canada using the Landsat satellite image archive. Environmental Research Letters 6: 045502. https: //doi.org/10.1088/1748-9326/6/4/045502

Godfrey, W. E. 1986. The Birds of Canada (revised edition). National Museums of Canada, Ottawa, Ontario, Canada.

Harrington, F. H. 1994. Fauna of the Torngat Mountains area. Unpublished report to Parks Canada. Mount Saint Vincent University, Halifax, Nova Scotia, Canada.

He, Y., X. Guo, P. Dixon, and J. Wilmshurst. 2008. Satellite monitoring of northern ecosystems using multi-sensors. Unpublished report to Parks Canada. Department of Geography, University of Saskatchewan, and Western and Northern Canada Service Centre, Parks Canada, Winnipeg, Manitoba, Canada.

Henden, J. A., N. G. Yoccoz, R. A. Ims, and K. Langeland. 2013. How spatial variation in areal extent and configuration of labile vegetation states affect the riparian bird community in Arctic tundra. PLoS ONE 8: e63312. https: //doi.org/10.1371/journal.pone.0063312

Hitch, A. T., and P. L. Leberg. 2007. Breeding distributions of North American bird species moving north as a result of climate change. Conservation Biology 21: 534-539. https://doi.org/10.1111/j.1523-1739.2006.00609.x

Ims, R. A., and J. A. Henden. 2012. Collapse of an Arctic bird community resulting from ungulate-induced loss of erect shrubs. Biological Conservation 149: 2-5. https://doi.org/10 .1016/j.biocon.2012.02.008
IPCC (Intergovernmental Panel on Climate Change). 2014. Climate change 2014: synthesis report. IPCC, Geneva, Switzerland.

KRG. 2005. Kuururjuaq park project (Monts-Torngat-etRivière Koroc): status report. Kativik Regional Government, Renewable Resources, Environmental and Land Use Planning Department, Kuujjuaq, Quebec, Canada. Accessed 25 April 2016. http://docs.nunavikparks.ca/Site CollectionDocuments/EN/Kuururjuaq StatusReport.pdf.

Mizel, J. D., J. H. Schmidt, C. L. McIntyre, and C. A. Roland. 2016. Rapidly shifting elevational distributions of passerine species parallel vegetation change in the subarctic. Ecosphere 7: e01264. https://doi.org/10.1002/ecs2.1264

Myers-Smith, I. H., B. C. Forbes, M. Wilmking, M. Hallinger, T. Lantz, D. Blok, K. D. Tape, M. MaciasFauria, U. Sass-Klaassen, E. Lévesque, S. Boudreau, P. Ropars, L. Hermanutz, A. Trant, L. Siegwart Collier, S. Weijers, J. Rozema, S. A. Rayback, N. M. Schmidt, G. Schaepman-Strub, S. Wipf, C. Rixen, C. B. Ménard, S. Venn, S. Goetz, L. Andreu-Hayles, S. Elmendorf, V. Ravolainen, J. Welker, P. Grogan, H. E. Epstein, and D. S. Hik. 2011. Shrub expansion in tundra ecosystems: dynamics, impacts and research priorities. Environmental Research Letters 6: 045509. https://doi.org/10.1088/17489326/6/4/045509

Myers-Smith, I. H., S. C. Elmendorf, P. S. A. Beck, M. Wilmking, M. Hallinger, D. Blok, K. D. Tape, S. A. Rayback, M. Macias-Fauria, B. C. Forbes, J. D. M. Speed, N. Boulanger-Lapointe, C. Rixen, E. Lévesque, N. M. Schmidt, C. Baittinger, A. J. Trant, L. Hermanutz, L. Siegwart Collier, M. A. Dawes, T. C. Lantz, S. Weijers, R. H. Jørgensen, A. Buchwal, A. Buras, A. T. Naito, V. Ravolainen, G. Schaepman-Strub, J. A. Wheeler, S. Wipf, K. C. Guay, D. S. Hik, and M. Vellend. 2015. Climate sensitivity of shrub growth across the tundra biome. Nature Climate Change 5: 887-891. https://doi.org/10.1038 /nclimate2697

Notzl, L., R. Greene, and J. L. Riley. 2013. Labrador Nature Atlas, Volume two: ecozones, ecoregions and ecodistricts. Nature Conservancy of Canada, Toronto, Ontario, Canada.

Ouellet, H. 1973. List of birds recorded at two localities on the east coast of Ungava Bay, Quebec, in June and July 1973. Unpublished report. National Museum of Canada, Ottawa, Ontario, Canada.

Ouellet, H. 1978. La vallée de la rivière Korok, une enclave forestière en toundra québécoise. Nord/North 25: 6-11.

Parks Canada. 2008. State of park report, Torngat Mountains National Park of Canada. Unpublished report. Parks Canada, Rocky Harbour, Newfoundland and Labrador, Canada.

Payette, S. 1983. The forest tundra and present tree lines of the northern Québec-Labrador Peninsula. Nordicana 47: 3-23.

Pouliot, D., R. Latifovic, and I. Olthof. 2009. Trends in vegetation NDVI from $1 \mathrm{~km}$ AVHRR data over Canada for the period 1985-2006. International Journal of Remote Sensing 30: 149-168. https://doi.org/10.1080/0143116080 2302090

Québec Breeding Bird Atlas. 2016. Atlas of the breeding birds of Québec, 2010-2014. Regroupement Québec Oiseaux, Environment and Climate Change Canada, and Bird Studies Canada, Québec, Quebec, Canada. Accessed 25 April 2016. http://www.atlas-oiseaux.qc.ca/index en.jsp. Quirouette, J., and P. Zorn. 2015. Subtle vegetation change Torngat Mountains. Unpublished report. Parks Canada, Gatineau, Quebec, Canada. 
Sokolov, V., D. Ehrich, N. G. Yoccoz, A. Sokolov, and N. Lecomte. 2012. Bird communities of the arctic shrub tundra of Yamal: habitat specialists and generalists. PLoS ONE 7: e50335. https://doi.org/10.1371/journal.pone.0050335

Stralberg, D., S. M. Matsuoka, C. M. Handel, F. K. A. Schmiegelow, A. Hamann, and E. M. Bayne. In press. Biogeography of boreal passerine range dynamics in western North America: past, present, and future. Ecography. https://doi.org/10.1111/ecog.02393

Thomas, C. D., and J. J. Lennon. 1999. Birds extend their ranges northwards. Nature 399: 213. https://doi.org/10.1038 120335

Thompson, S. J., C. M. Handel, R. M. Richardson, and L. B. McNew. 2016. When winners become losers: predicted nonlinear responses of Arctic birds to increasing woody vegetation. PLoS ONE 11: e0164755. https://doi.org/10 .1371 /journal.pone. 0164755

Todd, W. E. C. 1963. Birds of the Labrador Peninsula. Carnegie Museum and University of Toronto Press, Toronto, Ontario, Canada.

Tremblay, B., E. Lévesque, and S. Boudreau. 2012. Recent expansion of erect shrubs in the Low Arctic: evidence from eastern Nunavik. Environmental Research Letters 7: 035501. https://doi.org/10.1088/1748-9326/7/3/035501

Way, R. G., and A. E. Viau. 2014. Natural and forced air temperature variability in the Labrador region of Canada during the past century. Theoretical and Applied Climatology 121: 413-424. https://doi.org/10.1007/s00704-014-1248-2

Whitaker, D. M., and S. W. Eaton. 2014. Northern Waterthrush (Parkesia noveboracensis). In The Birds of North America Online. Edited by A. Poole. Cornell Laboratory of Ornithology, Ithaca, New York, USA. https://doi.org/10 $.2173 /$ bna. 182

Wilson, K. S., M. W. Basterfield, C. Furgal, T. Sheldon, E. Allen, the communities of Nain and Kangiqsualujjuaq, and The Co-operative Management Board for the Torngat Mountains National Park. 2014. Torngat Mountains caribou herd Inuit knowledge, culture and values study. Final report to Nunatsiavut government. Makivik Corporation, Parks Canada, and the Torngat Wildlife and Plants Co-Management Board, Nain, Newfoundland and Labrador, Canada.

Received 26 April 2016

Accepted 28 March 2017 